\title{
Mitteilungen der GI im Informatik Spektrum 4/2020
}

Online publiziert: 22. Juni 2020

๑) Springer-Verlag GmbH Deutschland, ein Teil von Springer Nature 2020

\section{Aus Vorstand und Präsidium}

\section{Ordentliche Mitgliederversammlung der GI}

Aufgrund der Corona-Pandemie ist derzeit unsicher, wie die Ordentliche Mitgliederversammlung der GI abgehalten werden kann. Bitte schauen Sie für mögliche Aktualisierungen auf die GI-Webseite https://gi.de/.

\section{Beschlüsse der Vorstandssitzung vom 31. März 2020}

- Dr. habil. Matthias Thimm als deutscher Vertreter im TC 12 der IFIP (Nachfolge Ulrich Furbach)

\section{Aus der Geschäftsstelle}

\section{Mensch-Technik-Interaktion für digitale Souveränität: neue Projekte der GI}

Im Forschungsprogramm „Technik zum Menschen bringen" hat sich das Bundesministerium für Bildung und Forschung (BMBF) zum Ziel gesetzt, Innovationen in der Mensch-Technik-Interaktion zu fördern, die Nutzerinnen und Nutzer zu unterstützen, digitale Inhalte und ihre eigenen Daten informiert und mündig zu nutzen und $\mathrm{zu}$ verwalten.

Digitale Souveränität in diesem Kontext soll über die rechtliche Basis hinausgehen - es geht um die Steigerung von Kompetenzen im digitalen Raum und Instrumente, die Nachvollziehbarkeit erhöhen und dazu beitragen, kompetente Entscheidungen zu treffen. Die Gesellschaft für Informatik (GI) verfügt innerhalb ihrer Mitgliedschaft über groBe Expertise zu diesen Fragestellungen. Aus dieser Position wird sich die GI in den nächsten Jahren stark im Themenkomplex digitale Souveränität mit Projekten zur MenschTechnik-Interaktion einbringen.

In einem interdisziplinären Verbund mit Partnern von der RWTH Aachen, der Universität Bremen, der Otto-Friedrich-Universität Bamberg, der Stiftung Digitale Chancen und Garmin Würzburg GmbH wird beispielsweise unter- sucht, welches Potenzial interaktive Datenschutzlösungen zur Steigerung der Souveränität von Smart-Wearables-Nutzerinnen und Nutzer haben.

Um die vielfältigen Fragestellungen und noch zu entwickelnden Lösungen zu integrieren, wird die GI gemeinsam mit der AlgorithmWatch gGmbH das „Netzwerk Digitale Souveränität" ins Leben rufen, in dem relevante Erkenntnisse für die interessierte Öffentlichkeit, die Politik und die Wirtschaft aufbereitet werden.

\section{Presse- und Öffentlichkeitsarbeit der GI}

\section{$\mathrm{KI}$ in der Arbeitswelt: Forschungsprojekt zur Nachvollziehbarkeit algorithmischer Entscheidungssysteme gestartet (25. Mai 2020)}

Das Forschungsprojekt „KI Testing \& Auditing“ im Auftrag des Observatoriums „Künstliche Intelligenz in Arbeit und Gesellschaft" des Bundesarbeitsministeriums geht der Frage nach, wie sinnvolle Kontroll- und Testverfahren für Künstliche-Intelligenz-Systeme aussehen können.

Der zunehmende Einsatz von algorithmischen Entscheidungssystemen (ADM) bringt weitreichende Veränderungen für die Arbeitswelt mit sich. Insbesondere im Personalmanagement werden Entscheidungen zur Personalauswahl und -führung zunehmend durch ADM-Systeme vorbereitet. Auch im direkten Arbeitsumfeld interagieren Arbeitnehmerinnen und Arbeitnehmer zunehmend mit ,intelligenten“ Systemen. Wie können in diesem Rahmen Verfahren aussehen, die einen nachvollziehbaren, beherrschbaren und diskriminierungsfreien Einsatz von „Künstlicher Intelligenz“ (KI) sicherstellen? Wie lassen sich diese durchführen und welche institutionellen Anforderungen müssen dafür beachtet werden?

Der Klärung dieser Fragen wird sich die Gesellschaft für Informatik e.V. (GI) im Auftrag des KI-Observatoriums des Bundesministeriums für Arbeit und Soziales (BMAS) in einem 20-monatigen Forschungsprojekt gemeinsam mit Fraunhofer IESE, dem Algorithm Accountability Lab an der TU Kaiserslautern, dem Institut für 
Rechtsinformatik an der Universität des Saarlandes und der Stiftung Neue Verantwortung widmen.

\section{Handlungsempfehlungen für die Bildungspolitik: GI startet "Offensive Digitale Schultransformation“ (18. Mai 2020)}

Gemeinsam mit einem breiten Netzwerk aus Wissenschaft, Zivilgesellschaft und Wirtschaft hat die Gesellschaft für Informatik e.V. (GI) die „Offensive Digitale Schultransformation" ins Leben gerufen und fordert die Bildungspolitik in der Corona-Krise zum Handeln auf.

Vor dem Hintergrund der Corona-Krise hat die Gesellschaft für Informatik gemeinsam mit dem Bitkom, dem eco Verband der Internetwirtschaft, dem Deutschen Lehrerverband sowie zahlreichen weiteren Partnerinnen und Partnern die „Offensive Digitale Schultransformation“ (\#OdigS) gestartet. Mit ihr wollen die beteiligten Organisationen aus Wissenschaft, Wirtschaft und Zivilgesellschaft einen konstruktiven Beitrag zur aktuellen Diskussion um „digitale“ Bildungspolitik leisten. Im Rahmen der Initiative haben unterschiedliche Bildungsexpertinnen und -experten sieben konkrete Handlungsempfehlungen an die Politik formuliert, um zentrale Herausforderungen und offensichtlich gewordene Schwächen des aktuellen Bildungswesens zu adressieren.

\section{GI kritisiert „Datenspende-App“ des Robert-Koch- Instituts (9. Mai 2020)}

Im Kampf gegen Corona hat das Robert-Koch-Institut zu einer Datenspende via App aufgerufen. Die GI kritisiert, dass die Anwendung im Hinblick auf Datenschutz und ITSicherheit nicht die grundlegenden Anforderungen erfüllt. Die GI bedauert, dass damit eine Chance vergeben wurde, das Vertrauen der Bürgerinnen und Bürger in digitale Anwendungen zur Eindämmung des Corona-Virus zu stärken.

Im Mai hat das Robert-Koch-Institut (RKI) eine App veröffentlicht, über die Nutzerinnen und Nutzer ihre Daten der Wissenschaft zur Verfügung stellen können. Die Daten sollen dem RKI helfen, die Ausbreitung sowie die mögliche Dunkelziffer an Coronavirus-Infektionen besser einschätzen zu können. Die Gesellschaft für Informatik e. V. (GI) ist davon überzeugt, dass digitale Hilfsmittel bei der Eindämmung von Neuinfektionen und der Nachverfolgung helfen können. Dabei sollten sie jedoch dem Stand der Forschung und den höchsten Anforderungen in Sachen Transparenz, Zweckgebundenheit, Wahrung der Privatsphäre, Anonymisierung, Prüfbarkeit, Verschlüsselung und Datensparsamkeit entsprechen.

Den kompletten Text der Pressemitteilungen finden Sie unter https://gi.de/aktuelles/presse.

\section{Tagungsankündigungen}

\section{BTW 2021 - „DB meets Al“, Dresden, March 12-18, 2021}

BTW („Fachtagung für Business, Technologie und Web“) is the major event for the German database community. It serves as a central forum for the exchange of information among around 300 scientists, practitioners and users on current issues in information and database system technology, such as Big Data Analytics, modern hardware and storage technologies or the use of artificial intelligence for system optimization. "DB meets AI" is the main theme of the BTW'21, which aims to stimulate the transfer of knowledge between database and AI experts. (Abb. 1).

BTW'21 will take place from 8 to 12 March 2021 in the beautiful baroque city of Dresden in the heart of Saxony, under the auspices of Saxony's Prime Minister Michael Kretschmer. Organizer of the conference is the Database Systems Group headed by Wolfgang Lehner.

In addition to the scientific program with international keynote speakers, the five-day conference includes a data science challenge, the awarding of prizes to outstanding dissertation projects, system demonstrations and panel discussions as well as a cultural program.

The program on Monday and Tuesday will be giving the opportunity for a "warm-up" in workshop-style. For example, SPP 2037 will offer a workshop and the RTG 1907 is inviting to a symposium.

During the main conference days on Wednesday and Thursday, the conference will focus on the scientific program. In addition to the presentation of research papers, invited papers, tutorial, we are welcoming renowned keynote speakers like Wang-Chiew (Megagon Labs, CA) and Stratos Idreos, (Harvard DASlab).
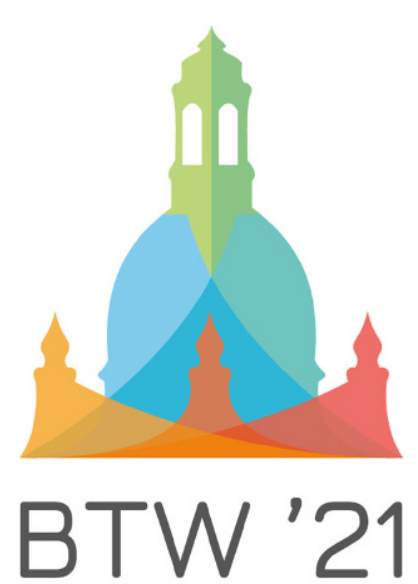

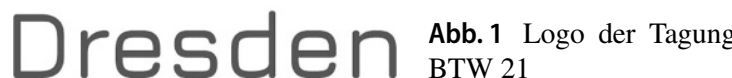


Thematic tracks of the program focus on "Database Technology", "ML \& Data Science", "Data Integration", "Semantic Data Management", "Streaming", and "(Industrial) Use Cases \& Applications". Submissions for these tracks are accepted by 25.09.2020 via ConfTool.

A special program for young scientists is integrated into the conference in order to foster early exchange between aspiring young academics and experienced scientists and practitioners.

Special events like the Data Science Challenge and Awards for the Best Dissertation, Best Paper and Best Demo will strengthen the interactive character of the conference. Please see the BTW conference website for more information and deadlines.

On Friday, the conference day will focus on industrial contributions and is organized jointly with the "Center for Scalable Data Analytics and Artificial Intelligence Dresden/Leipzig" (ScaDS) as co-organizer of this "conference within a conference". (Abb. 2).

A wide range of partners from international, national and regional industry display their appreciation and support by sponsoring BTW'21. We are very grateful for this generous commitment and we are still relying on further support from this side.

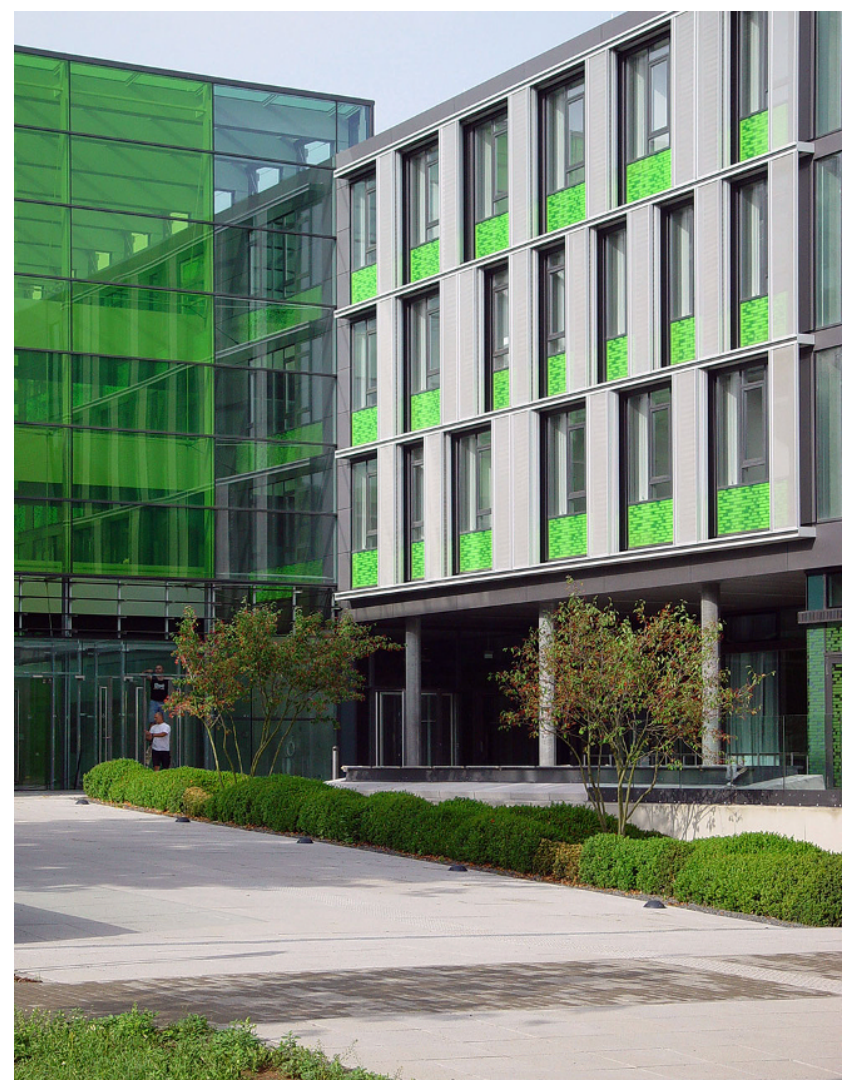

Abb. 2 Fakultät für Informatik der TU Dresden. Quelle: TU Dresden
During the festive conference banquet on Thursday night, there will be ample opportunity to meet and mix. The impressive foyer of "Deutsches Hygiene-Museum" in the city center is the venue of this social event. Karl August Lingner, the manufacturer of the famous mouthwash Odol, founded this institution in 1912. Since then, the museum has always been at the cutting edge of science - thus serving as a perfectly fitting location for the conference dinner.

Likewise, the city of Dresden combines rich history with innovative present and an overwhelming beauty of the surrounding landscapes. Why not extend your stay and enjoy some days of a perfect work-life-balance in Saxony?!

An incalculable situation as the current pandemic does not only produce adverse circumstances for preparing an event like this. It also poses new challenges that will surely contribute to the agenda and that will give discussions a new twist.

In any case, as every conference, the BTW'21 relies on active involvement of its participants. Therefore, please consider contributing by submissions, commitment in the program, workshop suggestions, and more. Please check online for news and deadlines and follow us on Twitter (\#BTW21Dresden).

\section{Bundesweit Informatiknachwuchs fördern (BWINF)}

\section{Bundeswettbewerb Informatik: Internationale Teilnahme an der 2. Runde}

210 Schülerinnen und Schüler haben an der 2. Runde des Bundeswettbewerbs Informatik (BwInf) teilgenommen. Die rund 30 Besten von ihnen qualifizieren sich für die Endrunde im Herbst. Der Bundeswettbewerb erreicht deutsche Schülerinnen und Schüler im In- und Ausland. Die weitesten Einsendungen kamen aus dem rund $1373 \mathrm{~km}$ entfernten Rom und aus Warschau $(1133 \mathrm{~km})$. Während in der ersten Runde Einzel- und Gruppenarbeit erlaubt ist, war in der zweiten Runde ausschließlich selbstständige Einzelarbeit gefordert. Die Bewertung erfolgt durch eine relative Platzierung der Arbeiten. Wegen der Corona-bedingten Beschränkungen wurde die Bewertung erstmals digital durchgeführt: eine Premiere, die geglückt ist. Die Bewerter kamen nicht zusammen, sondern trafen sich u.a. online in Konferenzen (siehe Foto). In die 1. Runde des Bundeswettbewerbs waren 1462 Jugendlichen gestartet. Insgesamt hatten sich 786 Teilnehmende für die 2. Runde qualifiziert. (Abb. 3). 

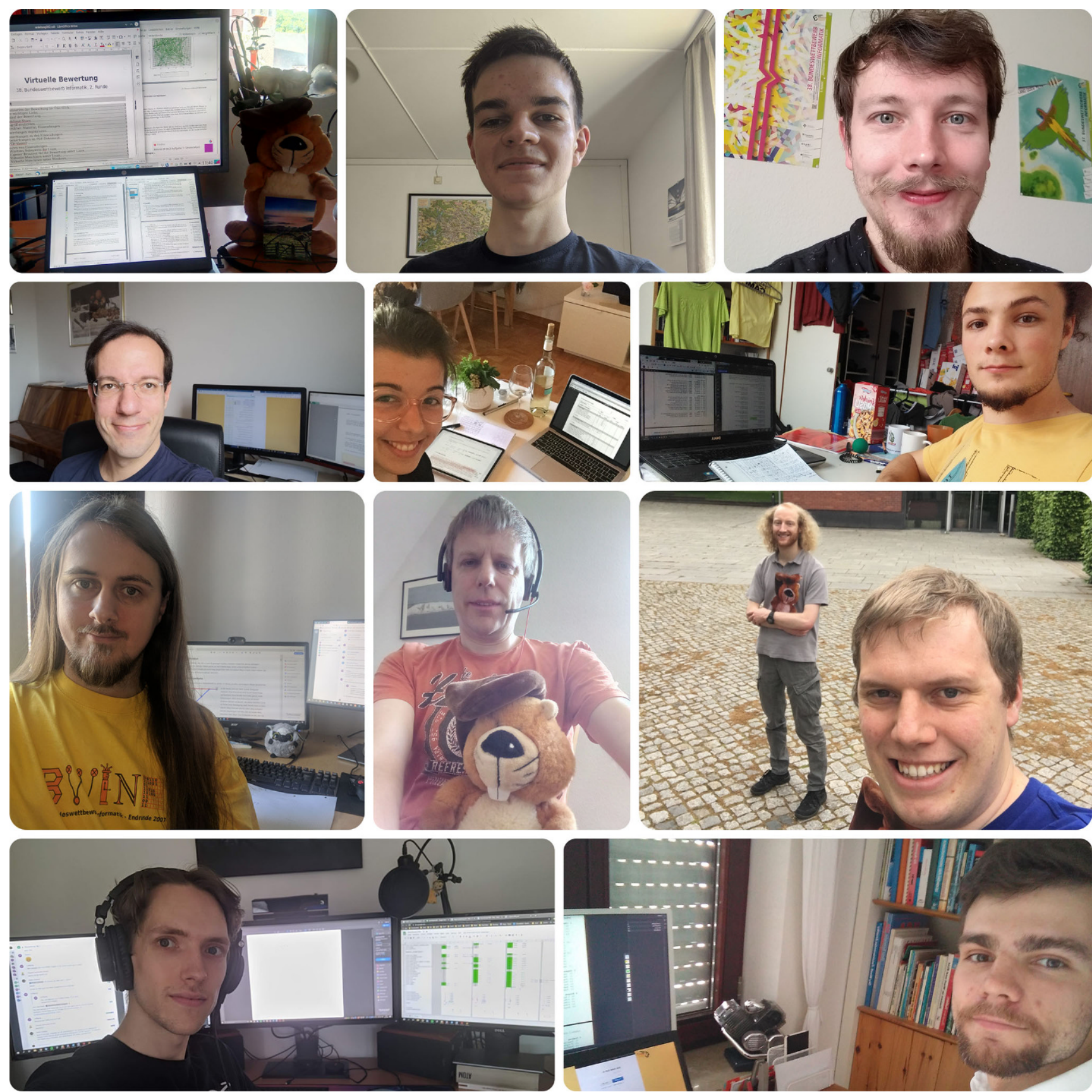

Abb. 3 BWINF-Bewertung online. Quelle: BWINF

\section{Jugendwettbewerb Informatik 2020: 2. Runde endet mit Teilnahmerekord}

Nachdem mit 22.689 Schülerinnen und Schülern so viele Teilnehmende beim Jugendwettbewerb Informatik (JwInf) starteten (Vorjahr: 16.494) wie nie, ist auch die Zahl der Kinder und Jugendlichen, die bei der 2. Runde dabei waren, gestiegen.

6569 Teilnehmende waren es 2020, ein Jahr zuvor nahmen 5244 an der 2. Runde teil. Mit 2048 Mädchen in der
2. Runde hat sich die Mädchenquote auf rund $32 \%$ (Vorjahr: $30,2 \%)$ gesteigert. Die Mädchenquote der 1. Runde lag bei $31,1 \%$.

\section{Runde}

Über eine Qualifikation für die letzte Runde entscheidet die Gesamtpunktzahl der 1. und 2. Runde. 3136 Schülerinnen und Schüler haben sich für die 3. Runde des Jugendwettbewerbs qualifiziert, darunter 691 Mädchen (22\%). Die 
3. Runde startet am 1. September 2020 zeitgleich mit dem 39. Bundeswettbewerb Informatik.

\section{Jugendwettbewerb international}

Auch international stieß der Jugendwettbewerb auf großes Interesse: Schülerinnen und Schüler an Deutschen Schulen in Portugal, Griechenland, Italien, Österreich, Spanien, Ukraine und Ghana stellten sich den JwInf-Aufgaben.

\section{Weitere Programmieraufgaben}

Für alle Schülerinnen und Schüler, die über den Wettbewerb hinaus noch Lust auf Programmier-Herausforderungen haben, gibt es auf jwinf.de unter dem Titel „Herausforderungen" weitere Wettbewerbsangebote. Diese bestehen überwiegend aus Aufgaben aus den vergangenen Wettbewerben, aber auch aus einigen neue Aufgaben.

\section{Tagungen}

\subsubsection{0-09.09.2020}

Magdeburg

Tagung Mensch und Computer 2020

MuC2020

https://muc2020.mensch-und-computer.de

07.09.2020-11.09.2020

Leipzig

Digital Operating Room Summer School DORS

https://www.iccas.de/en/dors/

21.09.2020-25.09.2020

Bamberg

43rd German Conference on Artificial Intelligence

KI 2020

https://ki2020.uni-bamberg.de/

\subsubsection{0-01.10.2020}

Karlsruhe

50. Jahrestagung der Gesellschaft für Informatik

INFORMATIK 2020

https://informatik2020.de/

\subsubsection{0-30.10.2020}

\section{Essen}

The 15th Workshop in Primary and Secondary Computing Education

WIPSCE 2020

https://www.wipsce.org/2020/

\section{$01.12 .2020-03.12 .2020$}

Berlin

9th International Conference on Performance Evaluation and Modeling in Wired and Wireless Networks PEMWN 2020

https://sites.google.com/view/pemwn2020/home

\subsubsection{1-26.02.2012}

Braunschweig

Software Engineering 2021

SE 2021

https://se-2021.tu-bs.de/

\subsubsection{1-12.03.2021}

Dresden

19. Fachtagung für Datenbanksysteme für Business, Technologie und Web

BTW 2021

http://btw-konferenz.de/2021

\subsubsection{1-10.09.2021}

Wuppertal

GI-Fachtagung Informatik und Schule - Lehrerbildung

INFOS 2021

http://www.infos2021.de/ 